\title{
Inflammatory markers are beneficial in the early stages of cerebral venous thrombosis
}

\author{
Los marcadores inflamatorios son beneficiosos en las primeras etapas de la trombosis \\ venosa cerebral
}

Aysel Tekeșin', Abdulkadir Tunç²

\begin{abstract}
Cerebral vein thrombosis (CVT) is a rare but serious cause of acute stroke. Inflammation is a hypothetical etiological factor in CVT. Objective: The aim of this study was to evaluate inflammatory marker levels in CVT patients and compare these with healthy individuals. Methods: This prospective case-control study was conducted with 36 newly-diagnosed CVT patients age- and sex-matched with 40 healthy individuals. The laboratory investigations included a serum hemogram, full biochemistry profiles, high sensitivity C-reactive protein (CRP) and erythrocyte sedimentation rate (ESR). Neutrophil-to-lymphocyte ratio (NLR), platelet-to-lymphocyte ratio (PLR), and monocyte-to-HDL cholesterol ratio (MHR) values were calculated and compared between the patients and healthy participants. Results: The mean age was $41.4 \pm 11.8$ years for patients, and $39.3 \pm 12.5$ for controls. Lymphocyte, total bilirubin, indirect bilirubin, and HDL levels were significantly lower in CVT patients ( $p$ < 0.05), while CRP, and ESR values were significantly higher. In the CVT patients the mean NLR and PLR values were significantly higher than in the control individuals. Smoking rates, alcohol consumption, white blood cell, neutrophil, platelet, and MHR values were similar in both groups ( $p>0.05$ ). Conclusions: We suggest that NLR, PLR, CRP, ESR, and bilirubin can be used in clinical practice for prediction of CVT in suspected patients as they are inexpensive parameters and widely available. However, further large-scale studies are required to confirm this relationship.
\end{abstract}

Keywords: Sinus thrombosis, intracranial; inflammation; laboratories.

\section{RESUMEN}

la trombosis de la vena cerebral (CVT) es una causa rara pero grave de accidente cerebrovascular agudo. La inflamación es un factor etiológico hipotético en CVT. Objetivo: El objetivo de este estudio fue evaluar los niveles de marcadores inflamatorios en pacientes con CVT y compararlos con los sujetos sanos. Métodos: Este estudio prospectivo de casos y controles se realizó con 36 pacientes con TVC recién diagnosticados y 40 sujetos sanos con edad y sexo similares. Las investigaciones de laboratorio incluyeron hemograma sérico, perfiles bioquímicos completos, proteína C-reactiva (CRP) de alta sensibilidad y velocidad de sedimentación eritrocitaria (ESR). Se calculó la relación de neutrófilos a linfocitos (NLR), relación de plaquetas a linfocitos (PLR) y monocitos a HDL-colesterol (MHR) y se compararon entre pacientes y sujetos sanos. Resultados: La edad media fue de 41,4 $\pm 11,8$ años para los pacientes y de 39,3 $\pm 12,5$ para los controles. Los niveles de linfocitos, bilirrubina total, bilirrubina indirecta y HDL fueron significativamente más bajos en pacientes con CVT ( $p \leq 0.05$ ), mientras que los valores de CRP y ESR fueron significativamente más altos. En los pacientes con CVT, los valores medios de NLR y PLR fueron significativamente más altos que en los sujetos control. Las tasas de tabaquismo, consumo de alcohol, glóbulos blancos, neutrófilos, plaquetas y MHR fueron similares en ambos grupos ( $p$ > 0.05). Conclusiones: Sugerimos que la NLR, la PLR, la CRP, la ESR y la bilirrubina se pueden usar en la práctica clínica para la predicción de la CVT en pacientes sospechosos, ya que son parámetros económicos y están ampliamente disponibles. Sin embargo, se requieren más estudios a gran escala para confirmar esta relación.

Palabras-clave: Trombosis de los senos intracraneales; inflamación; laboratorios.

Cerebral vein thrombosis (CVT) is a rare but serious cause of acute stroke ${ }^{1}$. It occurs frequently between 20 and 50 years and is three times more common in women than men $^{2}$. The underlying etiology is unknown in up to $30 \%$ of cases $^{1,2}$. Venous stasis, endothelial damage, genetic and acquired prothrombotic factors and inflammation have been shown to be responsible for the formation, growth, organization or recanalization of the thrombus ${ }^{3}$. In particular, a close link has been detected between inflammation and thrombosis in previous studies ${ }^{1,4}$.

In current clinical practice, high sensitivity C-reactive protein (CRP) and erythrocyte sedimentation rate (ESR) are the most widely used inflammatory markers ${ }^{5,6}$. The neutrophil-to-lymphocyte ratio (NLR) and platelet-to-lymphocyte

\footnotetext{
'Sağlık Bilimleri Üniversitesi, İstanbul Eğitim ve Arștırma Hastanesi, Nöroloji Kliniği, Istanbul, Turkey;

${ }^{2}$ Sakarya Universitesi, Egitim ve Arastirma Hastanesi, Nöroloji Kliniği, Sakarya, Turkey.

Abdulkadir Tunç (iD) https://orcid.org/0000-0002-9747-5285

Correspondence: Abdulkadir Tunç; Sakarya Universitesi Egitim ve Arastirma Hastanesi, Sakarya 54100, Turkey; E-mail:drkadirtunc@hotmail.com

Conflict of interest: There is no conflict of interest to declare.

Received 15 August 2018; Received in final form 11 October 2018; Accepted 05 November 2018.
} 
ratio (PLR), which are calculated from the white blood cell count are reported to be novel inflammatory biomarkers in patients with venous thrombosis and Guillain-Barré syndrome $^{7,8}$. Decreased high-density lipoprotein cholesterol (HDL-C) levels and increased monocyte counts were also found to be associated with inflammation, and the monocyte to HDL-C ratio (MHR) was suggested to be used as a novel inflammatory biomarker ${ }^{9,10}$. A significant relationship was shown between high bilirubin levels and anti-oxidation and anti-inflammation in various diseases ${ }^{11}$. Higher mean platelet volume (MPV) levels were found to be associated with worse prognosis in inflammatory bowel disease ${ }^{12}$.

Therefore, in this study we aimed to evaluate high sensitivity CRP, ESR, NLR, PLR, MHR, bilirubin, and MPV levels in CVT patients and compare these with levels measured in healthy individuals. The above-mentioned inflammatory markers have been evaluated separately in many studies ${ }^{5-12}$. However, this is the first study, in which they are evaluated together.

\section{METHODS}

This prospective case-control study was conducted with 36 newly diagnosed CVT patients within 24 hours after the onset of symptoms, and 40 age- and sex-matched healthy individuals in our tertiary referral hospital. The study was approved by the Istanbul Training and Research Hospital ethics committee. An informed written consent was signed by all the participants. Exclusion criteria were as follows; pregnancy/puerperium, arterial stroke, acute myocardial infarction, diabetes mellitus, hypertension, infection (at admission or up to seven days prior), peripheral vascular disease, autoimmune disease, any inflammatory condition, malignancy, epileptic seizures and the patients under medical treatment with any anti-inflammatory medications, anti-aggregants, anticoagulants, and lipid-lowering drugs.

The diagnosis of CVT was based on a clinical evaluation, cranial magnetic resonance imaging (MRI), and MR-venography. The patients were divided into two subgroups according to the presence or absence of MRI parenchymal lesions, and number of involved sinuses (one sinus, or two or more sinuses). Clinical severity was evaluated with the National Institutes of Health Stroke Scale (NIHSS) ${ }^{13}$.

The healthy controls were selected from the patient's relatives or hospital staff members. The individuals who had any disease that could affect the laboratory tests were excluded.

The blood samples were obtained by careful venipuncture during emergency admission, before medical treatments. Samples for hematological tests were collected in EDTA tubes, and in dry tubes for biochemical tests. The laboratory investigations included a serum hemogram, full biochemistry profiles including HDL, bilirubin, high sensitivity CRP and ESR, which were measured using automated standard laboratory methods. An automated hematology analyzer XE-1200 (Sysmex, Kobe, Japan) was used for complete blood count measurements. A molecular analyzer (Roche Diagnostics, Mannheim, Germany) was used for the biochemical measurements. High sensitivity CRP measurements were done using an automated analyzer (Beckman Coulter IMMAGE) using nephelometric measurement.

A computerized database was used to collect the laboratory data. The findings were compared between the groups. The NLR, PLR, and MHR ratios were calculated and compared between the patients and healthy participants.

\section{Statistical analysis}

The data were transferred to the IBM SPSS Statistics 22.0 program and the analyses were completed. Mean, standard deviation, median, lowest-highest, frequency and ratio were included in the descriptive statistics of the data. The distribution of the variables was measured by the KolmogorovSmirnov test. The independent samples t test and MannWhitney $U$ test were used in the analysis of quantitative independent data. A chi-square test was applied to analyze the significance of the multiple comparison of relative frequencies among the groups, and the Fisher test was used when the chi-square test did not meet the conditions. Spearman's correlation was used for correlation analysis. The limit for statistical significance was accepted as $\mathrm{p}<0.05$.

\section{RESULTS}

The demographic and clinical characteristics of the patients and controls are summarized in Table 1 . The participants were aged between 23 and 62 years. Four patients were in the postpartum period and one patient was newly diagnosed with Behçet's disease with no systemic features. Twelve patients were excluded after considering the exclusion criteria (infections, malignancy, etc.). There were no significant differences in terms of smoking rates, alcohol consumption, neutrophils, direct bilirubin, and MHR between the two groups (Table 2).

The MPV, lymphocyte, total bilirubin, indirect bilirubin, and HDL levels were significantly lower in the CVT patients, while CRP and ESR values were significantly higher. The mean NLR and PLR values were also significantly higher than the control individuals $(\mathrm{p}=0.000, \mathrm{p}=0.003)$ (Table 2).

In patients with a thrombosis of two or more sinuses, PLR values were significantly higher $(p=0.013)$, while there was no difference in terms of NLR, MHR values, and other markers in the thrombosis of one sinus group, or two or more sinuses groups $(p>0.05)$. All of the patients underwent MRI and parenchymal lesions were detected in 16 patients. No significant differences were detected in any evaluated biomarker among the patients with or without parenchymal lesions $(\mathrm{p}>0.05)$. 
Table 1. Demographic characteristics and laboratory findings of all participants.

\begin{tabular}{|c|c|c|c|}
\hline Variable & $1 Q-3 Q$ & Median & Mean \pm SD / n-\% \\
\hline Age & $23.0-62.0$ & 39.0 & $40.3 \pm 12.2$ \\
\hline \multicolumn{4}{|l|}{ Gender } \\
\hline Female & & & $63,82.9 \%$ \\
\hline Male & & & $13,17.1 \%$ \\
\hline \multicolumn{4}{|l|}{ Smoking } \\
\hline$(+)$ & & & $22,28.9 \%$ \\
\hline$(-)$ & & & $54,71.1 \%$ \\
\hline \multicolumn{4}{|l|}{ Alcohol consumption } \\
\hline$(+)$ & & & $1,1.3 \%$ \\
\hline$(-)$ & & & $75,98.7 \%$ \\
\hline White blood cell & $6.3-8.6$ & 7.5 & $7.5 \pm 1.6$ \\
\hline Platelet & $219.8-323.5$ & 275.5 & $280.2 \pm 76.6$ \\
\hline Neutrophil & $3.5-5.3$ & 4.3 & $4.4 \pm .1 .3$ \\
\hline Lymphocyte & $1.8-2.7$ & 2.2 & $2.3 \pm 0.8$ \\
\hline Monocyte & $0.4-0.7$ & 0.5 & $0.5 \pm 0.2$ \\
\hline MPV & $8.8-10.4$ & 9.5 & $9.4 \pm 1.3$ \\
\hline $\mathrm{HDL}$ & $41.0-55.8$ & 48.0 & $49.5 \pm 13.7$ \\
\hline Total bilirubin & $0.4-0.8$ & 0.5 & $0.6 \pm 0.3$ \\
\hline Direct bilirubin & $0.1-0.2$ & 0.1 & $0.1 \pm 0.1$ \\
\hline Indirect bilirubin & $0.3-0.6$ & 0.4 & $0.5 \pm 0.2$ \\
\hline hsCRP & $0.2-0.7$ & 0.3 & $0.8 \pm 1.5$ \\
\hline ESR & $12.0-29.5$ & 18.0 & $20.9 \pm 14.0$ \\
\hline Monocyte/HDL & $0.0-0.0$ & 0.0 & $0.0 \pm 0.0$ \\
\hline Neutrophil/lymphocyte & $1.4-2.5$ & 1.9 & $2.2 \pm 1.5$ \\
\hline Platelet/lymphocyte & $93.0-152.0$ & 120.0 & $132.7 \pm 53.7$ \\
\hline
\end{tabular}

MPV: Mean platelet volume; HDL: High-density lipoprotein; hsCRP: High sensitivity C-reactive protein; ESR: Erythrocyte sedimentation rate

Table 2. Comparison of patients and controls according to demographic characteristics and laboratory findings.

\begin{tabular}{|c|c|c|c|c|c|c|}
\hline \multirow{2}{*}{ Variable } & \multicolumn{2}{|c|}{ Controls } & \multicolumn{2}{|c|}{ Patients } & \multirow{2}{*}{$p$-value } & \multirow{2}{*}{ Test } \\
\hline & $1 Q-3 Q$ & Median & $1 Q-3 Q$ & Median & & \\
\hline Age & $27.0-51.5$ & 36.5 & $29.5-52.8$ & 40.5 & 388 & $\mathrm{~m}$ \\
\hline \multicolumn{7}{|l|}{ Gender } \\
\hline Female & $33,82.5 \%$ & & $30,83.3 \%$ & & 0.923 & $x^{2}$ \\
\hline Male & $7,17.5 \%$ & & $6,16.7 \%$ & & & \\
\hline \multicolumn{7}{|l|}{ Smoking } \\
\hline$(+)$ & $10,25.0 \%$ & & $12,33.3 \%$ & & 0.424 & $x^{2}$ \\
\hline$(-)$ & $30,75.0 \%$ & & $24,66.7 \%$ & & & \\
\hline \multicolumn{7}{|l|}{ Alcohol consumption } \\
\hline$(+)$ & $0,0.0 \%$ & & $1,2.8 \%$ & & 0.474 & $x^{2}$ \\
\hline$(-)$ & $40,100 \%$ & & $35,97.2 \%$ & & & \\
\hline White blood cells & $6.3-8.8$ & 7.5 & $6.0-8.6$ & 7.6 & 0.827 & $\mathrm{~m}$ \\
\hline Platelet & $238.5-300.3$ & 271.5 & $205.3-344.8$ & 284.0 & 0.954 & $\mathrm{~m}$ \\
\hline Neutrophil & $3.5-4.8$ & 4.2 & $3.5-5.6$ & 4.7 & 0.134 & $\mathrm{~m}$ \\
\hline Lymphocyte & $2.0-3.3$ & 2.4 & $1.6-2.3$ & 2.0 & 0.001 & $\mathrm{~m}$ \\
\hline Monocyte & $0.4-0.7$ & 0.5 & $0.4-0.7$ & 0.5 & 0.450 & $\mathrm{~m}$ \\
\hline MPV & $9.3-10.8$ & 10.0 & $7.7-9.9$ & 9.1 & 0.000 & $\mathrm{~m}$ \\
\hline HDL & $45.3-58.8$ & 51.5 & $36.3-50.8$ & 44.0 & 0.004 & m \\
\hline Total bilirubin & $0.4-0.9$ & 0.6 & $0.3-0.6$ & 0.4 & 0.002 & $\mathrm{~m}$ \\
\hline Direct bilirubin & $0.1-0.2$ & 0.1 & $0.1-0.2$ & 0.1 & 0.426 & m \\
\hline Indirect billirubin & $0.3-0.7$ & 0.5 & $0.2-0.5$ & 0.3 & 0.000 & m \\
\hline hsCRP & $0.1-0.4$ & 0.3 & $0.3-1.5$ & 0.6 & 0.000 & $\mathrm{~m}$ \\
\hline ESR & $8.0-19.0$ & 13.5 & $16.5-37.8$ & 26.0 & 0.000 & $\mathrm{~m}$ \\
\hline Monocyte/HDL & $0.0-0.0$ & 0.0 & $0.0-0.0$ & 0.0 & 0.339 & $\mathrm{~m}$ \\
\hline Neutrophil / Lymphocyte & $1.2-2.1$ & 1.5 & $1.7-2.9$ & 2.2 & 0.000 & $\mathrm{~m}$ \\
\hline Platelet/ Lymphocyte & $81.1-140.5$ & 113.2 & $111.1-185.8$ & 132.9 & 0.003 & m \\
\hline
\end{tabular}

: Mann-Whitney u test; $x^{2}$ : Chi-square test; MPV: Mean platelet volume; HDL: High-density lipoprotein; hsCRP: High sensitivity C-reactive protein; ESR: Erythrocyte sedimentation rate. 
Table 3. Evaluation of the laboratory findings with logistic regression analysis.

\begin{tabular}{|c|c|c|c|c|c|c|}
\hline \multirow{2}{*}{ Variable } & \multicolumn{3}{|c|}{ Single variable model } & \multicolumn{3}{|c|}{ Multiple variable model } \\
\hline & OR & $95 \% \mathrm{Cl}$ & $p$-value & OR & $95 \% \mathrm{Cl}$ & $p$-value \\
\hline Lymphocyte & 0.266 & $0.117-0.605$ & 0.002 & & & \\
\hline MPV & 0.453 & $0.284-0.721$ & 0.001 & 0.277 & $0.114-0.673$ & 0.005 \\
\hline HDL & 0.962 & $0.924-1.001$ & 0.058 & & & \\
\hline Total bilirubin & 0.064 & $0.009-0.468$ & 0.007 & & & \\
\hline Indirect bilirubin & 0.025 & $0.002-0.285$ & 0.003 & & & \\
\hline hsCRP & 0.242 & $0.067-0.880$ & 0.031 & 4.761 & $1.064-1.273$ & 0.025 \\
\hline ESR & 1.107 & $1.049-1.169$ & 0.000 & 1.164 & & 0.001 \\
\hline Neutrophil/Lymphocyte & 2.709 & $1.323-5.547$ & 0.006 & & & \\
\hline Platelet/Lymphocyte & 1.014 & $1.003-1.025$ & 0.009 & & & \\
\hline
\end{tabular}

MPV: Mean platelet volume; HDL: High density lipoprotein; hsCRP: High sensitivity C-reactive protein; ESR: Erythrocyte sedimentation rate; OR: Odds ratio; Cl: Confidence interval.

Finally, clinical severity according to the NIHSS scores did not affect the evaluated biomarkers in CVT patients ( $\mathrm{p}>0.05)$.

The MPV, CRP, and ESR values were significantly different $(\mathrm{p}<0.05)$ in the case and control groups in the multivariate analysis (Table 3).

\section{DISCUSSION}

The preliminary results of our study showed that inflammation may be connected to the pathogenesis of CVT. The NLR, PLR, CRP and ESR values were significantly higher and bilirubin and MPV levels were significantly lower in CVT patients compared with the healthy participants in this study. No significant differences were found according to the presence or absence of MRI parenchymal lesions, and NIHSS scores in CVT patients. Only PLR values were significantly higher in patients with a thrombosis of two or more sinuses.

Several studies have been performed to show the relationship between inflammation and venous thrombosis in recent years ${ }^{4,5,8}$. It was pointed out, in an in vivo study, that neutrophils were responsible for the initiating stimuli in the thrombus formation and the propagation of the thrombus was contributed to by platelets ${ }^{14}$. High platelet counts were associated with an increased risk of venous thrombosis because of the location of platelet aggregates in the core of the thrombus. The platelet aggregates generate circulating microparticles in response to prohemostatic stimuli that are independent risk factors for venous thrombosis ${ }^{15,16}$.

The NLR and PLR are simply calculated biomarkers from the lymphocyte, neutrophil and platelet counts in the venous blood samples. They have been investigated in several studies and elevated levels were shown to be important biomarkers in coronary artery diseases ${ }^{17,18}$. The study by Artoni et al. ${ }^{8}$, that was performed with a large group of patients with venous thrombosis, showed a lack of association between high values of PLR and NLR and an increased risk of venous thrombosis. Another study from Turkey showed a significant association between elevated NLR and CVT patients compared with healthy controls ${ }^{19}$. Consistent with most of the previous studies, we found higher levels of NLR and PLR levels in CVT patients compared with the healthy controls.

The MPV is another biomarker that was used for the assessment of systemic inflammation in previous studies ${ }^{20,21}$. Our study was incompatible with these previous studies, possibly because of the low number of participants.

We found significantly higher CRP and ESR values in CVT patients. Similarly, previous studies have mostly reported elevated levels of both markers in inflammatory diseases ${ }^{5,6,22}$. Horvei et al. ${ }^{22}$ stated that low-grade inflammation, assessed by measurement of CRP, was associated with the risk of venous thrombosis.

A limited number of studies of the MHR have demonstrated the role of this ratio in predicting inflammation ${ }^{23,24}$. In a study of patients with venous thrombosis, it was shown that high monocyte counts were associated with venous thromboembolism, even within normal limits ${ }^{23}$. The MHR has been shown to be an independent predictor of cardiovascular events in chronic renal failure patients and a poor prognosis for cardiovascular mortality ${ }^{10}$. Our study did not show any relationship between the MHR and CVT. Further studies are needed to evaluate the possible relationship.

Some inflammatory diseases, like multiple sclerosis and systemic lupus erythematosus, were associated with lower levels of bilirubin in previous studies ${ }^{25,26}$. It was pointed out that serum bilirubin could provide a crucial protection against inflammation ${ }^{25}$. Similar to previous studies, we found lower levels of bilirubin in CVT patients compared with the control group.

Our study had some limitations. It was a single-center study and the number of patients were relatively low. Otherwise, it had a prospective design with similar groups. We calculated the aforementioned markers on admission. Control values would be valuable in the follow-up period. It was unclear whether the biomarkers and systemic inflammation had a causative relationship in our study and, finally, evaluation of oxidative stress biomarkers could be more valuable. 
In conclusion, our results suggest that NLR, PLR, CRP, ESR, and bilirubin can be used in clinical practice for prediction of CVT in suspected patients as they are inexpensive parameters and widely available. Also the results of this study add to the theory of inflammation in the pathomechanism of CVT, which needs further investigations involving patients with other venous thrombosis pathology (e.g. deep venous thrombosis of the limbs) to research the sensitivity in more detail.

\section{References}

1. Tufano A, Guida A, Coppola A, Nardo A, Di Capua M, Quintavalle G, et al. Risk factors and recurrent thrombotic episodes in patients with cerebral venous thrombosis. Blood Transfus. 2014 Jan;12 Suppl 1:s337-42.

2. Coutinho JM. Cerebral venous thrombosis. J Thromb Haemost. 2015 Jun;13 Suppl 1:S238-44. https://doi.org/10.1111/jth.12945

3. Vieira JP, Luis C, Monteiro JP, Temudo T, Campos MM, Quintas $S$, et al. Cerebral sinovenous thrombosis in children: clinical presentation and extension, localization and recanalization of thrombosis. Eur J Paediatr Neurol. 2010 Jan;14(1):80-5. https://doi.org/10.1016/j.ejpn.2008.12.004

4. Riva N, Donadini MP, Ageno W. Epidemiology and pathophysiology of venous thromboembolism: similarities with atherothrombosis and the role of inflammation. Thromb Haemost. 2015 Jun;113(6):1176-83. https://doi.org/10.1160/TH14-06-0563

5. Nagai M, Terao S, Yilmaz G, Yilmaz CE, Esmon CT, Watanabe $E$, et al. Roles of inflammation and the activated protein $C$ pathway in the brain edema associated with cerebral venous sinus thrombosis. Stroke. 2010 Jan;41(1):147-52. https://doi.org/10.1161/STROKEAHA.109.562983

6. Ammirati E, Moroni F, Norata GD, Magnoni M, Camici PG. Markers of inflammation associated with plaque progression and instability in patients with carotid atherosclerosis. Mediators Inflamm. 2015;2015:718329. https://doi.org/10.1155/2015/718329

7. Ozdemir HH. Analysis of the albumin level, neutrophillymphocyte ratio, and platelet-lymphocyte ratio in GuillainBarré syndrome. Arq Neuropsiquiatr. 2016 Sep;74(9):718-22. https://doi.org/10.1590/0004-282X20160132

8. Artoni A, Abbattista M, Bucciarelli P, Gianniello F, Scalambrino E, Pappalardo E, et al. Platelet to Lymphocyte Ratio and Neutrophil to Lymphocyte Ratio as Risk Factors for Venous Thrombosis. Clin Appl Thromb Hemost. 2018 Jul;24(5):808-14. https://doi.org/10.1177/1076029617733039

9. Çiçek G, Kundi H, Bozbay M, Yayla C, Uyarel H. The relationship between admission monocyte HDL-C ratio with short-term and long-term mortality among STEMI patients treated with successful primary PCl. Coron Artery Dis. 2016 May;27(3):176-84. https://doi.org/10.1097/MCA.0000000000000343

10. Kanbay M, Solak Y, Unal HU, Kurt YG, Gok M, Cetinkaya H, et al. Monocyte count/HDL cholesterol ratio and cardiovascular events in patients with chronic kidney disease. Int Urol Nephrol. 2014 Aug;46(8):1619-25. https://doi.org/10.1007/s11255-014-0730-1

11. KapitulnikJ. Bilirubin: an endogenous product of heme degradation with both cytotoxic and cytoprotective properties. Mol Pharmacol. 2004 Oct;66(4):773-9. https://doi.org/10.1124/mol.104.002832

12. Kapsoritakis AN, Koukourakis MI, Sfiridaki A, Potamianos SP, Kosmadaki MG, Koutroubakis IE, et al. Mean platelet volume: a useful marker of inflammatory bowel disease activity. Am J Gastroenterol. 2001 Mar;96(3):776-81. https://doi.org/10.1111/j.1572-0241.2001.03621.x

13. Stolz E, Rahimi A, Gerriets T, Kraus J, Kaps M. Cerebral venous thrombosis: an all or nothing disease? Prognostic factors and long-term outcome. Clin Neurol Neurosurg. 2005 Feb;107(2):99-107. https://doi.org/10.1016/j.clineuro.2004.06.002

14. Brühl ML, Stark K, Steinhart A, Chandraratne S, Konrad I, Lorenz $\mathrm{M}$, et al. Monocytes, neutrophils, and platelets cooperate to initiate and propagate venous thrombosis in mice in vivo. J Exp Med. 2012 Apr;209(4):819-35. https://doi.org/10.1084/jem.20112322

15. Wagner DD, Burger PC. Platelets in inflammation and thrombosis. Arterioscler Thromb Vasc Biol. 2003 Dec;23(12):2131-7. https://doi.org/10.1161/01.ATV.0000095974.95122.EC

16. Bucciarelli P, Martinelli I, Artoni A, Passamonti SM, Previtali E, Merati $G$, et al. Circulating microparticles and risk of venous thromboembolism. Thromb Res. 2012 May;129(5):591-7. https://doi.org/10.1016/j.thromres.2011.08.020

17. Núñez J, Núñez E, Bodí V, Sanchis J, Miñana G, Mainar L, et al. Usefulness of the neutrophil to lymphocyte ratio in predicting long-term mortality in ST segment elevation myocardial infarction. Am J Cardiol. 2008 Mar;101(6):747-52. https://doi.org/10.1016/j.amjcard.2007.11.004

18. Yüksel M, Yıldız A, Oylumlu M, Akyüz A, Aydın M, Kaya H, et al. The association between platelet/lymphocyte ratio and coronary artery disease severity. Anatol J Cardiol. 2015 Aug;15(8):640-7. https://doi.org/10.5152/akd.2014.5565

19. Kamıșlı S, Kamıșlı Ö, Gönüllü S, Kaplan Y, Özcan C. The prognostic value of increased leukocyte and neutrophil counts in the early phase of cerebral venous sinus thrombosis. Türk Beyin Damar Hast Derg. 2012;18(2):39-42. https://doi.org/10.5505/tbdhd.2012.43531

20. Yazici S, Yazici M, Erer B, Erer B, Calik Y, Ozhan H, et al. The platelet indices in patients with rheumatoid arthritis: mean platelet volume reflects disease activity. Platelets. 2010;21(2):122-5. https://doi.org/10.3109/09537100903474373

21. Sansanayudh N, Anothaisintawee T, Muntham D, McEvoy M, Attia J, Thakkinstian A. Mean platelet volume and coronary artery disease: a systematic review and meta-analysis. Int J Cardiol. 2014 Aug;175(3):433-40. https://doi.org/10.1016/j.ijcard.2014.06.028

22. Horvei LD, Grimnes G, Hindberg K, Mathiesen EB, Njølstad I, Wilsgaard T, et al. C-reactive protein, obesity, and the risk of arterial and venous thrombosis. J Thromb Haemost. 2016 Aug;14(8):1561-71. https://doi.org/10.1111/jth.13369

23. Rezende SM, Lijfering WM, Rosendaal FR, Cannegieter SC. Hematologic variables and venous thrombosis: red cell distribution width and blood monocyte count are associated with an increased risk. Haematologica. 2014 Jan;99(1):194-200. https://doi.org/10.3324/haematol.2013.083840

24. Efe TH, Arslan ED, Ertem AG, Yayla Ç, Felekoğlu MA, İnci S, et al. The prognostic value of the monocyte/hdl ratio in predicting short-term mortality in patients with acute pulmonary embolism. Koșuyolu Heart Journal. 2016;19(3):149-53. https://doi.org/10.5578/khj.23104

25. Peng F, Deng X, Yu Y, Chen X, Shen L, Zhong X, et al. Serum bilirubin concentrations and multiple sclerosis.J Clin Neurosci. 2011 Oct;18(10):1355-9. https://doi.org/10.1016/j.jocn.2011.02.023

26. Santos BH, Almeida CMR, Skare TL. Systemic Lupus Erythematosus activity and serum bilirubins. Acta Reumatol Port. 2013 OctDec;38(4):242-6. 